\title{
GOVERNMENT'S NEW POLICY ON THE ARRANGEMENTS OF PARTICIPATING INTEREST
}

\author{
${ }^{1}$ Indra Yulianingsih, 2 M. Ridwan Yusuf Algasahri \\ Faculty of Law, University of Trunojoyo Madura \\ email: 1indra.yulianingsih@trunojoyo.ac.id, 2160111100197@student.trunojoyo.ac.id
}

\begin{abstract}
The Oil and Gas Ministerial Regulation Number 37 of 2016 concerning Provisions for a $10 \%$ (ten percent) "Participating Interest" offer in the Oil and Gas Working Area has the aim of increasing the participation of district local governments through ownership of "participating interest". For this reason, this research is needed on the arrangement of "Participating Interest" in the management of Oil and Gas in Indonesia, constraints on implementing "Participating Interest" in the management of Oil and Gas in Sampang Regency and new policies to resolve problems regarding "Participating Interest".The research method used is Applied Legal Research, using statute, case approach, and a conceptual approach. The result of this research is that the implementation of the Regulation of the Minister of Energy and Mineral Resources regarding the distribution of the 10\% profit sharing in Sampang Regency has not been implemented. Therefore, a review of the ESDM Ministerial Regulation must be conducted regarding the provision of PI through BUMD and the participation of the private sector.
\end{abstract}

\section{Keywords: Oil and Gas, Participating Interest, PT.GSM}

\section{Introduction}

State control over natural resources is stated in Article 33 paragraph (3) of the 1945 Constitution of the Republic of Indonesia with the aim of maximizing the welfare and prosperity of the Indonesian people. Natural resources have two characteristics, namely renewable resources (renewable natural resources) and natural resources that are non-renewable (non-renewable natural resources). One type of nonrenewable natural resource in the mining sector, namely oil and natural gas. Oil and gas mining operations carry several relatively high risks. This activity has a relatively higher physical and social impact compared to commodity companies in general (Sutedi, 2010, p.43). The government's authority in regulating mining, regarding the utilization and management of oil and gas in a comprehensive manner is regulated in Law Number 22 Year 2001 regarding Oil and Gas Mining (Oil and Gas Law). Upstream Oil and Gas Business Activities are exploration and exploitation of oil and gas which can be carried out by companies that have obtained the approval of the Minister of 
Energy and Mineral Resources, which in this case is represented by the Special Task Force for Upstream Oil and Gas Business Activities (SKK Migas). SKK Migas represents the minister in approving the management of Oil and Gas.

The enactment of the Oil and Gas Law in 2001 did not unify the regulations regarding these activities. In the implementation of management and implementation, there are still many overlaps in terms of authority. This begins with a change in authority in local government. The dynamics of the formation of regulations regarding regional government were initially regulated in Law Number 32 of 2004 concerning Regional Government. Article 18 Paragraph (1) explains that regional governments can carry out exploration and exploitation activities of natural resources contained in the sea area. If a local government has an administrative territorial area towards the sea, then this has opened the widest opportunity to manage these activities in its territory.

However, then the issuance of Law Number 23 of 2014 concerning Regional Government (Regional Government Law) which causes changes to the authority of local governments as stipulated in point Article 18 Paragraph (1) of Law Number 32 Year 2004 becomes invalid. This is based on the provision of Article 14 Paragraph (3) of Law Number 23 of 2014 which explains that the management of oil and gas, which was previously the authority of the regional government, becomes the authority of the central government.

Furthermore, in order to provide protection and carry out the best possible management of natural resources, clear, systematic and non-conflicting regulations are needed. In order to provide legal certainty, the Ministry of Energy and Mineral Resources issued a regulation in the form of Minister of Energy and Mineral Resources Regulation Number 37 of 2016 concerning Provisions for the 10\% (ten percent) Participating Interest in the Oil and Gas Working Area. This stipulation is in the context of increasing the participation of the national region through participating interest (PI) ownership in the cooperation contract and to implement the provisions of Government Regulation Number 55 of 2009 concerning Upstream Oil and Gas Business Activities.

Article 2 Minister of Energy and Mineral Resources Regulation No. 37 of 2016 explains that regions are entitled to a Participating Interest (PI) of $10 \%$ (ten percent) after the approval of the field development plan for the first time in production activities, both on land and / or offshore waters with the provision that the area distance is up to 12 (twelve) miles to a work area. Therefore, to get Participating Interest, a region needs to form a Regional Owned Enterprise (BUMD). 
The issuance of this regulation from the Ministry of Energy and Mineral Resources has generated a lot of thoughts among local governments. The East Java Provincial Government and the Sampang Regency government, for example, to obtain the PI according to Article 2 of the Minister of Energy and Mineral Resources, there is an obligation for cooperation contract contractors (KKKS) to offer PI to BUMD as much as $10 \%$. However, because now the 0 (zero) area within the sea area (0-4) miles has become the authority of the provincial government based on the Minister of Energy and Mineral Resources Regulation Article 4 letter $b$, the allocation is for Provincial $B U M D$ s. Meanwhile, if viewed in terms of the location of the company, it is located in the Sampang district government area. So based on Article 4 (a) Minister of Energy and Mineral Resources Regulation number 37 of 2016, the provincial government and district government can make an agreement to share the results that the contractor has offered by $10 \%$.

One example of cooperation in forming a subsidiary to handle PI can be found in the subsidiary of Petronas Jawa Timur Sampang Energi (PJSE). In which the formation of PJSE is operationally carried out by Petronas Jatim Utama and PT. Geliat Sampang Mandiri (PT. GSM), which has been established since 2008. However, in its development, PT. GSM only manages part of the oil and gas sector and in 2013 it was hit by problems that resulted in internal problems at PT. GSM which impacted its performance, especially in the management of Oil and Gas. This led to a restructuring within PT.GSM carried out by reshuffling several sections such as the board of directors and their staff to follow up on the existence of the Minister of Energy and Mineral Resources.

Up to the mid-2020 PT.GSM has not received the 10\% PI amount, even though the Minister of Energy and Mineral Resources regulation regarding the offer was stipulated since 2016. This is because PT.GSM is only a participant and not a technical implementer of exploration and exploitation activities, so that the full control is under the Province. East Java. The existence of the phrase in the substance of the regulation that PI will only be given through BUMD complicates the position of the district government. As we know in the formation of $B U M D$ and capital participation, it requires a very large amount of funds, making it difficult for the district government to get the $10 \%$ amount. Moreover, in Article 3 letter a of the Minister of Energy and Mineral Resources Regulation states that shares fully belong to the Regional Government. On the other hand, the Energy and Mineral Resources ministerial regulation does not explain the criteria for using this PI in protecting the sustainability of the marine environment. The government is more focused on its management without regulating the impact on the environment. 
Based on this, researchers want to research further related to government policies on Participating Interest of 10\%. Based on data obtained from PT.GSM, until 2020 the local government of Sampang Regency through the BUMD, namely PT.GSM, has not received the profit sharing amount called PI of $10 \%$ since the enactment of the Minister of Energy and Mineral Resources Regulation. For this reason, the research problem can be formulated as follows; how to regulate Participating Interest in the management of Oil and Gas in Indonesia; what are the obstacles to implementing Participating Interest in the management of Oil and Gas in Sampang Regency; and what is the new policy to resolve Participating Interest setting issues.

\section{Research methods}

\section{Type of research}

The type of research used is an applied legal research (Muhammad, 2004, p.52), the research approaches used in this study are the statute approach, the case approach, and the conceptual approach. The sources of legal materials and data that the authors use in this research are primary data and secondary data.

The source of the primary legal materials used is the 1945 Constitution of the Republic of Indonesia, Law no. 22 of 2001 concerning Oil and Gas, Law no. 23 of 2014 concerning Regional Government, Presidential Decree No. 9 of 2013 concerning the Implementation of Upstream Oil and Gas Business Activities, Minister of Energy and Mineral Resources Regulation No. 37 of 2016 concerning Participating Interest, Constitutional Court Decision No. 35 / PUU-X / 2012 and Sampang District Regulation No. 9 of 2019 concerning PT.GSM (Perseroda)

Secondary data in this study are data that provide an explanation for primary data. Starting with the results of interviews and data collection with agencies related to the implementation of PI in the management of Oil and Gas in the Sampang District.

\section{Legal material collection techniques}

The collection of legal materials is carried out by means of literature studies and statutory studies as well as data collection by compiling several regulations related to the problem that is being studied. Furthermore, interviews are conducted to gather information and a brief discussion between the author, someone who hopes to get 
information, and the informant, a person or legal entity who is considered to have important information related to an object (Krisyanto, 2012, p.100). In this study, the authors will discuss the application of PI in the management of oil and gas exploration and exploitation activities.

\section{Legal Material Analysis}

Analysis of legal materials used in the writing of this study by carrying out a comprehensive study of the collection and processing, data and legal materials, to produce a core result of the problem. It is also supported by several theories and concepts that the authors have compiled in this study (Fajar, 2010, p.183). The data that has been obtained based on this research method includes interviews, observations, and literature studies which are closely related to the management and implementation of oil and gas exploration and exploitation.

\section{Results and Discussions}

\section{Regulation of Participating Interest in Oil and Gas Management in Indonesia}

Participating Interest in the management of Oil and Gas in Indonesia is regulated in Article 2 of the Minister of Energy and Mineral Resources Regulation Number 37 of 2016, that regions are entitled to a Participating Interest of $10 \%$ in the management of Oil and Gas. The issuance of the Minister of Energy and Mineral Resources Regulation Number 37 of 2016 is a basic milestone in terms of progress in managing oil and gas governance in Indonesia. With the direct involvement of the regions in order to prosper and prosper the people in areas that are geographically the owners of the management area and who are also affected by oil and gas exploration and exploitation activities.

The provisions for Participating Interest in oil and gas management contain several important aspects as follows:

1. Cooperation contract contractors $(K K K S)$ who will later manage exploration and exploitation activities in work areas that have been determined by law, that those who have oil and gas producing working areas in the form of land and offshore waters up to 12 miles are obliged to make bids to region through its $B U M D$ by ten percent $(10 \%)$. The ownership shares of BUMD are fully owned by the local 
government and legalized through regional regulations and do not carry out other activities besides the management of the PI.

2. The bidding scheme in this Regulation of the Minister of Energy and Human Resources is carried out by preparing the appointment of $B U M D$. This BUMD only manages PI for one work area, no more. Then the selected $B U M D$ will appoint a regional limited company (perseroda). The basis for its formation is stipulated in regional regulations and the shares are purely owned by the regional government and there is no interference from the private sector.

\section{New Constraints and Policies for Implementing Participating Interest in Oil andGas Management in Sampang Regency}

Article 7 paragraph (6) letter c in the Minister of Energy and Mineral Resources Regulation related to PI is a major obstacle for local governments in their efforts to obtain the amount of PI. Where in the substance of the discussion of the article it prohibits the existence of a private sector in the share ownership of regional companies (Perseroda), because cooperation is very important in the aspect of funding.

Oil and gas exploration and exploitation activities in Indonesia are one of the industries with a very high amount of capital and risk. So, in order to share the risk and the amount of the funding cost, it is necessary to involve the private sector with $B U M D$ in the management of PI. This is very influential significantly because it will produce professional commitment with the capital that is owned together. This also helps empower regional BUMDs, transfers expertise directly or indirectly, and can support the development of the investment climate in the regions. Another advantage with the direct involvement of the private sector in the management of PI is that the full income will be obtained but the risk is borne by the private party.

We can see the obstacles for implementing Participating Interest in Sampang Regency at PT. GSM as the technical operator of oil and gas management in Sampang district is experiencing several obstacles. among them; First, the exploration and exploitation implementation area are in accordance with the Minister of Energy and Mineral Resources Article 4 letter a, which states that the area 0-4 nautical miles from the offshore belongs to the province, so that the Sampang regency sub-district cannot become a technical implementer in realizing PI. This makes the company only able to wait without clear certainty when the $10 \%$ PI will be received by the Sampang Regency Government through other Regional Original Revenue funds. 
The second obstacle, when compared with other regional organizations or companies, PT.GSM is still far away in terms of organization and management. On the other hand, PT.GSM is not only engaged in dealing with 10\% PI issues, but is stated in Article 5 of the Sampang Regency Regional Regulation No. 9 of 2019 concerning the Establishment of PT.GSM, including upstream oil and gas activities, downstream oil and gas activities, oil and gas shorebase, and others. Third, related to the substance of Article 3 letter a in the Minister of Energy and Mineral Resources Regulation which states that the amount of capital participation must be fully by the Regional Government and there is no private interference in its shares because oil and gas management requires a very large initial capital and has a high risk.

For this reason, it is necessary to review the article that regulates the provision of $10 \%$ PI through BUMD, so that the amount of PI can be obtained immediately by the Sampang Regency Government through PT.GSM as BUMD which will later be felt by the Sampang Regency community. The distribution of participation rights should be given directly to the relevant Regional Government so that it can directly become income for Regional Original Income. The authority should be given to district / city governments that directly feel the social and environmental impacts so that they can participate in technical implementation in order to accelerate the obtaining of the $10 \%$ PI amount.

\section{Conclusion}

1. Participating Interest in the management of Oil and Gas in Indonesia is regulated in Article 2 of the Minister of Energy and Mineral Resources Regulation Number 37 of 2016, that regions are entitled to $10 \%$ Participating Interest in the management of Oil and Gas.

The implementation of Participating Interest in the management of Oil and Gas in Sampang Regency which is based on the provisions of the Minister of Energy and Mineral Resources Number 37 of 2016 in Sampang Regency has not yet been realized due to several obstacles including the regulation of Article 2 of the Minister of Energy and Mineral Resources which requires the form of $B U M D$. For this reason, a new policy is needed for the implementation of Participating Interest by reviewing the Article which regulates that the provision of PI $10 \%$ through BUMD, so that the amount of PI can be immediately obtained by the Regency Government to be empowered by the Community PI distribution should be given directly to the Regional Government so that it can directly become an income for Regional Original Revenue. 


\section{REFERENCES}

Fajar, M \& Ahmad, Y. (2010). Dualisme penelitian hukum normative \& empiris. Pustaka Pelajar.

Krisyanto. (2012). Riset komunikasi. Prenada Media Group.

Muhammad, A. (2004). Hukum dan penelitian hukum. Citra Aditya Bakti.

Sutedi, A. (2010) Hukum pertambangan. Sinar Grafika. 